\title{
The Hemoglobin E Thalassemias
}

\author{
Suthat Fucharoen ${ }^{1}$ and David J. Weatherall ${ }^{2}$ \\ ${ }^{1}$ Thalassemia Research Centre, Institute of Science and Technology for Research and Development, Mahidol \\ University, Bangkok, Thailand \\ ${ }^{2}$ Weatherall Institute of Molecular Medicine, University of Oxford, John Radcliffe Hospital, Oxford OX3 9DS, \\ United Kingdom \\ Correspondence: grsfc@mahidol.ac.th
}

Hemoglobin $\mathrm{E}(\mathrm{HbE})$ is an extremely common structural hemoglobin variant that occurs at high frequencies throughout many Asian countries. It is a $\beta$-hemoglobin variant, which is produced at a slightly reduced rate and hence has the phenotype of a mild form of $\beta$ thalassemia. Its interactions with different forms of $\alpha$ thalassemia result in a wide variety of clinical disorders, whereas its coinheritance with $\beta$ thalassemia, a condition called hemoglobin $\mathrm{E} \beta$ thalassemia, is by far the most common severe form of $\beta$ thalassemia in Asia and, globally, comprises approximately $50 \%$ of the clinically severe $\beta$-thalassemia disorders.

\begin{abstract}
A s discussed by Williams and Weatherall A(2012), HbE occurs at an extremely high frequency in many countries in Asia. Because there is also a high frequency of different $\beta$ thalassemia alleles in these populations, the coinheritance of $\mathrm{HbE}$ and $\beta$ thalassemia, $\mathrm{HbE} \beta$ thalassemia, occurs very frequently. Similarly, because different forms of $\alpha$ thalassemia are also very common in these countries, $\mathrm{HbE}$ also occurs together with them, producing a complex series of phenotypes.

The first description of $\mathrm{HbE} \beta$ thalassemia appeared in a paper by Minnich and her colleagues in 1954 under what, at the time, was the rather surprising title "Mediterranean Anaemia: A study of 32 cases in Thailand" (Minnich et al. 1954). In the same year, the first electrophoretic identification of HbE was reported independently (Itano et al. 1954). The first detailed clinical description of $\mathrm{HbE} \beta$ thalassemia was reported in
\end{abstract}

1956 by Chernoff and colleagues (1956). Much later, groups in Thailand began a detailed analysis of the interaction of the various forms of $\alpha$ thalassemia with $\mathrm{HbE}$, which result in a complex series of phenotypes, most of which are much milder than $\mathrm{HbE} \beta$ thalassemia (Wasi et al. 1969).

\section{MOLECULAR PATHOLOGY AND PROPERTIES OF HEMOGLOBIN E}

At least in vitro, $\mathrm{HbE}$ appears to be mildly unstable and shows increased sensitivity to oxidants (Frischer and Bowman 1975). However, in vitro studies of hemoglobin synthesis do not show evidence of instability similar to that found in other unstable hemoglobin variants, although $\mathrm{HbE}$ is unstable at increased temperatures, similar to those that would occur in a wide range of infective diseases (Rees et al. 1998). The whole-blood oxygen dissociation curves of

Editors: David Weatherall, Alan N. Schechter, and David G. Nathan

Additional Perspectives on Hemoglobin and Its Diseases available at www.perspectivesinmedicine.org

Copyright (C) 2012 Cold Spring Harbor Laboratory Press; all rights reserved; doi: 10.1101/cshperspect.a011734

Cite this article as Cold Spring Harb Perspect Med 2012;2:a011734 
homozygotes for HbE appear to be normal or very slightly right-shifted. $\mathrm{HbE}$ is synthesized at a slightly reduced rate and homozygotes show mild globin-chain imbalance, similar to that observed in $\beta$-thalassemia heterozygotes. It is caused by a base substitution at codon 26 of the $\beta$-globin gene, GAG-AAG, which results in the substitution of lysine for glutamic acid. This mutation also activates a cryptic splice site that causes abnormal messenger RNA processing (Orkin et al. 1982). Because the normal donor site has to compete with this new site, the level of normally spliced $\beta^{\mathrm{E}}$ messenger RNA is reduced (Traeger et al. 1980), resulting in the clinical phenotype of a mild form of $\beta$ thalassemia.

The heterozygous state for $\mathrm{HbE}$ is characterized by minimal morphological abnormalities of the red cells and normal red cell indices; $\mathrm{HbE}$ constitutes $25 \%-30 \%$ of the hemoglobin (Fig. 1). Homozygotes for HbE have hypochromic microcytic red cells with significant morphological abnormalities including increased numbers of target cells (Fig. 2). They are mildly anemic and the overall hematological findings are very similar to those of heterozygous $\beta$ thalassemia.

\section{THE INTERACTIONS OF HEMOGLOBIN E WITH DIFFERENT FORMS OF THALASSEMIA}

Although $\mathrm{HbE}$ alone does not cause any significant clinical problems, its interactions with various forms of $\alpha$ and $\beta$ thalassemia produce a very wide range of clinical syndromes of varying

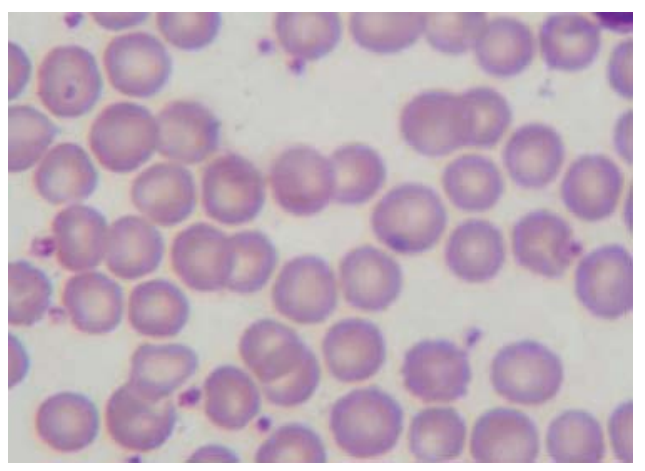

Figure 1. The peripheral blood film in hemoglobin E trait showing normal red cell morphology.

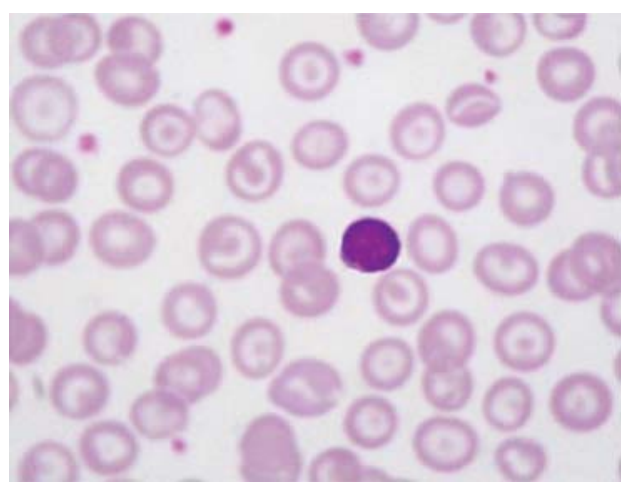

Figure 2. The peripheral blood film in the homozygous state for hemoglobin E showing large numbers of target cells.

severity. The molecular basis for the different forms of $\alpha$ and $\beta$ thalassemia, which are coinherited with $\mathrm{HbE}$, are described by Thein (2012) and Higgs (2012).

The various interactions of $\mathrm{HbE}$ and $\alpha$ thalassemia, which have been defined in the Thai population, and occur elsewhere in SE Asia, are described by their particular hemoglobin constitutions (Table 1). Heterozygotes for $\mathrm{HbE}$, which are also heterozygous for $\alpha^{+}$thalassemia $(-\alpha / \alpha \alpha)$, have similar levels of $\mathrm{HbE}$ to $\mathrm{HbE}$ heterozygotes, whereas those that are heterozygous for $\alpha^{0}$ thalassemia $(-/ \alpha \alpha)$ have mild thalassemic red cell changes and the level of $\mathrm{HbE}$ ranges between $19 \%$ and $21 \%$. HbE heterozygotes who also inherit the genotype of $\mathrm{HbH}$ disease $(-/-\alpha)$ have a marked decrease of $\mathrm{HbE}$ in the $13 \%-15 \%$ range and a thalassemic disorder of intermediate severity, which is called HbAE Bart's disease.

Hemoglobin E homozygotes who coinherit the heterozygous state for $\alpha^{+}$or $\alpha^{0}$ thalassemia have a mild hypochromic microcytic anemia with slightly elevated levels of HbF. Those who coinherit the genotype of $\mathrm{HbH}$ disease have a thalassemic disorder of intermediate severity with moderate anemia and elevated levels of $\mathrm{HbF}$ and Bart's, a condition called EF Bart's disease.

The compound heterozygous state for $\mathrm{HbE}$ and $\beta$ thalassemia, $\mathrm{HbE} \beta$ thalassemia, is a remarkably heterogenous disease with a phenotype ranging from mild anemia to the most severe forms of $\beta$-thalassemia major (Weatherall 


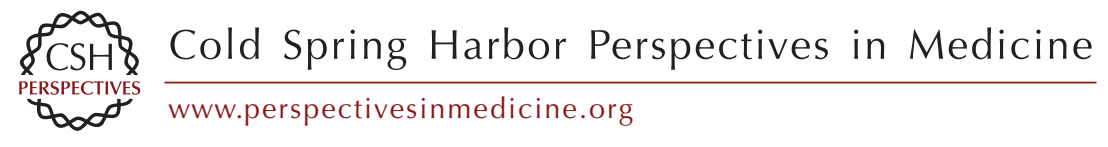

Table 1. Hematological data and clinical picture of subjects with HbE with different kinds of $\alpha$-globin gene interactions

\begin{tabular}{|c|c|c|c|c|c|c|c|c|}
\hline $\mathrm{Hb} \mathrm{E}$ & $\begin{array}{l}\alpha \text {-Globin } \\
\text { gene }\end{array}$ & $\mathrm{Hb}(\mathrm{g} / \mathrm{dl})$ & $\mathrm{MCV}(\mathrm{fl})$ & Hb typing & $\mathrm{Hb}$ E (\%) & HbBart's (\%) & $\mathrm{Hb} F(\%)$ & Clinical \\
\hline \multirow[t]{4}{*}{$\mathrm{Hb} \mathrm{E}$ heterozygote } & $\alpha \alpha / \alpha \alpha$ & $12.8 \pm 1.5$ & $84 \pm 5$ & EA & $29 \pm 2.3$ & - & $0.9 \pm 0.7$ & Normal \\
\hline & $-\alpha / \alpha \alpha$ & $13.1 \pm 1.4$ & $88 \pm 4$ & EA & $28 \pm 1.5$ & - & $0.7 \pm 0.6$ & Normal \\
\hline & $-/ \alpha \alpha$ & $12.5 \pm 1.4$ & $77 \pm 5$ & EA & $21 \pm 1.2$ & - & $0.9 \pm 0.4$ & Normal \\
\hline & $-/-\alpha$ & $9.1 \pm 1.1$ & $60 \pm 3$ & EFA Bart's & $13 \pm 2.1$ & $4.5 \pm 1.9$ & $2.2 \pm 1.9$ & Thal intermedia (AEBart's disease) \\
\hline \multirow[t]{4}{*}{ Hb E homozygote } & $\alpha \alpha / \alpha \alpha$ & $10.6 \pm 1.2$ & $65 \pm 3$ & $\mathrm{EF}$ & $88 \pm 2.6$ & - & $3.6 \pm 1.6$ & Normal \\
\hline & $-\alpha / \alpha \alpha$ & $11.0 \pm 1.6$ & $65 \pm 4$ & $\mathrm{EF}$ & $87 \pm 3.3$ & - & $4.8 \pm 3.7$ & Normal \\
\hline & $-/ \alpha \alpha$ & $10.5 \pm 2.4$ & $64 \pm 7$ & $\mathrm{EF}$ & $88 \pm 5.7$ & - & $3.8 \pm 2.1$ & Normal \\
\hline & $-/-\alpha$ & $7.5 \pm 0.8$ & $60 \pm 2$ & EF Bart's & $81 \pm 1.5$ & $4.2 \pm 1.1$ & $6.4 \pm 1.2$ & Thal intermedia (EFBart's disease) \\
\hline \multirow[t]{4}{*}{$\mathrm{Hb}$ E $\beta$ thalassemia } & $\alpha \alpha / \alpha \alpha$ & $7.1 \pm 1.4$ & $59 \pm 3$ & $\mathrm{EF}$ & $58 \pm 9.5$ & - & $38 \pm 11.7$ & Mild to severe disease \\
\hline & $-\alpha / \alpha \alpha$ & $8.5 \pm 1.1$ & $55 \pm 3$ & $\mathrm{EF}$ & $71 \pm 7.5$ & - & $24 \pm 8.7$ & Mild disease \\
\hline & $-/ \alpha \alpha$ & $9.3 \pm 0.5$ & $52 \pm 1$ & $\mathrm{EF}$ & $84 \pm 3.8$ & - & $12 \pm 2.5$ & Mild disease \\
\hline & $-/-\alpha$ & $7.6 \pm 1.2$ & $61 \pm 2$ & EF Bart's & $82 \pm 2.5$ & $1.5 \pm 0.3$ & $5.5 \pm 0.7$ & Thal intermedia (EFBart's disease) \\
\hline
\end{tabular}


and Clegg 2001). This condition may also be coinherited with a variety of different forms of $\alpha$ thalassemia. The coinheritance of the heterozygous states for $\alpha^{+}$and $\alpha^{0}$ thalassemia have an ameliorating effect on the disease, whereas those who also inherit the genotype of $\mathrm{HbH}$ disease have a form of HbEF Bart's disease, as described above.

These complex interactions, which are summarized in Table 1, produce three significant clinical disorders; HbAE Bart's disease, $\mathrm{HbEF}$ Bart's disease, and $\mathrm{HbE} \beta$ thalassemia.

\section{HbAE BART'S DISEASE}

This thalassemia syndrome is characterized by the presence of $\mathrm{HbA}, \mathrm{HbE}$, and $\mathrm{Hb}$ Bart's, and results from the interaction of the genotype of $\mathrm{HbH}$ disease (see Higgs 2012; Vichinsky 2012) with heterozygous HbE (Wasi et al. 1967; Thonglairuam et al. 1989). Two common subtypes of HbAE Bart's disease have been observed: $\alpha^{+}$ thalassemia $/ \alpha^{0}$ thalassemia- $\mathrm{A} / \mathrm{E}$ and $\alpha^{0}$ thalassemia/Hb Constant Spring-A/E. Clinically, $\mathrm{HbAE}$ Bart's disease is similar to $\mathrm{HbH}$ disease, and like the latter, the $\alpha^{0}$ thalassemia/Hb Constant Spring interaction is more severe (see Vichinsky 2012). However, in this syndrome there are no hemolytic crises during stress similar to those seen in $\mathrm{HbH}$ disease. The amount of $\mathrm{HbE}$ is decreased to $13 \%-15 \%$. This is because $\alpha$ globin chains have a lower affinity for $\beta^{\mathrm{E}}$ than $\beta^{\mathrm{A}}$-globin chains. Small amounts of Hb Bart's are always present in this genotype and intraerythrocytic inclusion bodies ( $\mathrm{HbH}$ inclusions) can be demonstrated in $\sim 5 \%$ of the erythrocytes, indicating the presence of small amounts of $\mathrm{HbH}$ that is insufficient to be detected by electrophoresis.

The diagnosis of this disorder requires detailed family studies together with DNA analysis to define the type of $\alpha$ thalassemia. Management is similar to HbH disease (see Vichinsky 2012).

\section{HbEF BART'S DISEASE}

HbEF Bart's disease is characterized by the presence of $\mathrm{HbE}, \mathrm{HbF}$, and $\mathrm{Hb}$ Bart's (Fucharoen et al. 1988b). $\mathrm{HbE}$ constitutes $\sim 80 \%$ and $\mathrm{HbF}$
$10 \%$ of the hemoglobin; the remainder is $\mathrm{Hb}$ Bart's. The presence of $\mathrm{Hb}$ Bart's indicates that there are excess $\gamma$-globin chains. However, no inclusion bodies or $\mathrm{HbH}$ are present, probably because the abnormal $\beta^{\mathrm{E}}$-globin chains do not form tetramers. Four genotypes of HbEF Bart's disease have been identified. They result from interactions between the genotype for $\mathrm{HbH}$ disease, either $\alpha^{0}$ thalassemia $/ \alpha^{+}$thalassemia or $\alpha^{0}$ thalassemia/Hb Constant Spring, with either homozygous $\mathrm{HbE}$ or $\mathrm{HbE} \beta$ thalassemia. $\mathrm{Hb}$ Constant Spring and small amounts of $\mathrm{HbA}$ may be observed in patients with the $\alpha^{0}$ thalassemia/Hb Constant Spring and $\mathrm{HbE} \beta^{+}$thalassemia genotype. To differentiate among these genotypes, family studies and further investigation by DNA analysis are required.

Overall, the interactions of the different genotypes for $\mathrm{HbH}$ disease with the homozygous state for $\mathrm{HbE}$ produce relatively mild forms of thalassemia intermedia, not dissimilar to $\mathrm{HbH}$ disease (see Vichinsky 2012). Their interactions with $\mathrm{HbE} \beta$ thalassemia are more complex and clinically variable, and are discussed in more detail in the next section.

\section{HEMOGLOBIN E $\beta$ THALASSEMIA}

In general, $\mathrm{HbE} \beta$ thalassemia is a thalassemia syndrome of intermediate severity with a very heterogeneous clinical spectrum. Two types have been described, depending on the presence or absence of $\mathrm{HbA}$. In $\mathrm{HbE}, \beta^{0}$ thalassemia, $\beta^{\mathrm{A}}$-globin chains are not synthesized and the condition is characterized by the production of $\mathrm{HbE}$ and $\mathrm{HbF}$ without detectable $\mathrm{HbA}$; $\mathrm{HbE}$ constitutes between $30 \%$ and $70 \%$ of the hemoglobin with the remainder $\mathrm{HbF}$. Variable amounts of $\mathrm{HbA}$ are detected, in addition to $\mathrm{HbE}$ and $\mathrm{HbF}$, in $\mathrm{HbE} \beta^{+}$ thalassemia. Different $\beta^{+}$thalassemia mutations result in variable severity of the disease, reflecting different levels of $\mathrm{HbA}$.

\section{Pathophysiology}

The pathophysiology of $\mathrm{HbE} \beta$ thalassemia reflects both the reduced output of $\mathrm{HbE}$ together with the added globin-chain imbalance consequent on the coinheritance of $\beta$ thalassemia. 
Although early studies suggested that $\mathrm{HbE}$ is slightly unstable and may precipitate under conditions of oxidative stress, later biosynthetic analyses showed little evidence of its instability in the red cells of patients with $\mathrm{HbE} \beta$ thalassemia. The one exception was if the cells were exposed to increased temperatures at the level that might be encountered in severe forms of infection at which there was evidence of instability (Rees et al. 1998). However, the remarkable ameliorating effect on the phenotype that results from the coinheritance of $\alpha$ thalassemia or other modifiers of the degree of globin chain imbalance (see later section) suggests that defective $\beta$ chain synthesis is the major factor in the pathophysiology of this condition (reviewed by Weatherall and Clegg 2001). Like other forms of severe $\beta$ thalassemia, there is marked expansion of the erythroid bone marrow with ineffective erythropoiesis. Interestingly, using a combination of electron-microscopic and immunocytochemical studies, Wickramasinghe and Lee (1997) demonstrated that the erythroblast inclusions in the bone marrow of patients with this condition consist entirely of precipitated $\alpha$ chains; there is no evidence of coprecipitation of $\beta^{\mathrm{E}}$ chains. Therefore the mechanisms of damage to red cells and their precursors are similar to those described in other forms of $\beta$ thalassemia (see Nienhuis and Nathan 2012).

Recent studies have suggested that there are important differences in the compensatory mechanisms between $\mathrm{HbE} \beta$ thalassemia and other forms of severe thalassemia intermedia. In particular, patients with $\mathrm{HbE} \beta$ thalassemia appear to be able to compensate for anemia by a right shift in their oxygen dissociation curves, unlike those with many other forms of $\beta$-thalassemia intermedia (Allen et al. 2010). This probably reflects both the properties of $\mathrm{HbE}$ and the lower mean levels of $\mathrm{HbF}$ that occur in $\mathrm{HbE} \beta$ thalassemia compared with other forms of $\beta$-thalassemia intermedia. Studies of the erythropoietin response to anemia in this condition have shown that hemoglobin level and age are independent variables with respect to the erythropoietin level and that there is a relative reduction in response to a particular hemoglobin level with aging (O'Donnell et al.
2007). This may be at least partly responsible for some of the remarkable phenotypic heterogeneity observed during the early years of development in babies with $\mathrm{HbE} \beta$ thalassemia.

\section{Clinical Features}

One of the most striking features of $\mathrm{HbE} \beta$ thalassemia is its remarkable clinical heterogeneity. At one end of the spectrum, there are patients whose clinical course is almost indistinguishable from that of severe $\beta$-thalassemia major; whereas at the other end, there are patients who grow and develop normally without the need for blood transfusion, albeit often at a relatively low hemoglobin level.

At birth, infants with severe $\mathrm{HbE} \beta$ thalassemia are asymptomatic because $\mathrm{HbF}$ levels are high. As $\mathrm{HbF}$ production decreases and is replaced by $\mathrm{HbE}$ at 6-12 months of age, anemia with splenomegaly develops. Signs of impaired growth appear during the first decade of life. The initial complaints vary from patient to patient, and several symptoms usually appear simultaneously (Table 2). Most common are the development of a mass in the left upper quadrant and pallor. With time and without transfusions, anemia, jaundice, hepatosplenomegaly, growth

Table 2. Presenting symptoms in $378 \mathrm{HbE} \beta$-thalassemia patients in Thailand

\begin{tabular}{|c|c|c|}
\hline Symptoms & Number & $\%$ \\
\hline 1. Pallor & 150 & 39.7 \\
\hline 2. Fever & 72 & 19.1 \\
\hline 3. Abdominal mass & 36 & 9.5 \\
\hline 4. Abdominal pain & 23 & 6.1 \\
\hline $\begin{array}{l}\text { 5. Combined: Abdominal mass } \\
\text { and pain }\end{array}$ & 21 & 5.6 \\
\hline 6. Yellow eyes ( jaundice) & 16 & 4.2 \\
\hline 7. Edema & 9 & 2.4 \\
\hline 8. Pregnancy with anemia & 3 & 0.8 \\
\hline 9. Bone pain & 3 & 0.8 \\
\hline 10. Paraplegia & 2 & 0.5 \\
\hline 11. Headache and dizziness & 2 & 0.5 \\
\hline 12. Miscellaneous ${ }^{\mathrm{a}}$ & 41 & 10.8 \\
\hline Total & 378 & 100 \\
\hline
\end{tabular}

${ }^{\mathrm{a}}$ Miscellaneous includes lymphadenopathy, skin rashes, chest pain, request for plastic surgery, joint pain, and cases with multiple symptoms. 
Table 3. Clinical signs in 378 adult HbE $\beta$-thalassemia patients in Thailand

\begin{tabular}{|c|c|c|}
\hline $\operatorname{Sign}^{\mathrm{a}}$ & Number & $\%$ \\
\hline 1. Splenomegaly & 369 & 97.6 \\
\hline 2. Jaundice & 350 & 92.6 \\
\hline 3. Hepatomegaly & 337 & 89.1 \\
\hline 4. Thalassemic facies & 313 & 82.8 \\
\hline 5. Growth retardation & 284 & 75.1 \\
\hline 6. Anemia & 152 & 40.2 \\
\hline 7. Abnormal cardiovascular system ${ }^{\mathrm{b}}$ & 70 & 18.5 \\
\hline 8. Respiratory tract infection & 44 & 11.6 \\
\hline 9. Arthritis and bone pain & 40 & 10.6 \\
\hline 10. Abnormal neurological system ${ }^{c}$ & 32 & 8.5 \\
\hline 11. Chronic leg ulcer & 31 & 8.2 \\
\hline 12. Soft tissue infection & 7 & 1.8 \\
\hline
\end{tabular}

${ }^{\mathrm{a}}$ Most patients have more than one clinical sign.

${ }^{\mathrm{b}}$ Abnormal cardiovascular manifestations are mainly related to congestive heart failure (50 cases), deep vein thrombosis (five cases), pericarditis (four cases), and others.

${ }^{c}$ Abnormal neurological features are mainly weakness of both hands (14 cases), headache (11 cases), and paraplegia (two cases).

retardation, and thalassemic facies evolve (Table 3). Absence of secondary sexual development is common and chronic leg ulcers are sometimes observed. These manifestations, which are secondary to decreased oxygen delivery to tissue, ineffective erythropoiesis, and iron overload, resemble those of $\beta$-thalassemia major.

Patients with the milder forms of $\mathrm{HbE} \beta$ thalassemia tend to grow and develop reasonably well during early childhood and are fully active. There may be some delay in the pubertal growth spurt and in the appearance of secondary sexual characteristics but they usually attain a reasonable height and sexual maturation. Further work is required to determine whether they develop the later complications that have been described in older patients with other forms of thalassemia intermedia, such as renal disease, pulmonary hypertension, cerebral infarcts, and others (see Musallam et al. 2012). Certainly some of them accumulate iron through increased absorption and may develop associated endocrine complications including diabetes. Furthermore, there is undoubtedly phenotypic instability in the early years of life; in a series of children observed over 15 years with $\mathrm{HbE}$ $\beta$ thalassemia in Sri Lanka, at least 20 cases changed from a mild to a more severe phenotype during the first 15 years of life.

\section{Laboratory Findings}

The steady-state hemoglobin levels in $\mathrm{HbE} \beta$ thalassemia range widely between the different phenotypes, from $3 \mathrm{~g} / \mathrm{dl}$ or less to as high as $11 \mathrm{~g} / \mathrm{dl}$. The red-cell indices and morphological changes are similar to those described in other forms of severe $\beta$ thalassemia (Fig. 3). Hemoglobin analysis reveals a preponderance of $\mathrm{HbE}$ with low levels of $\mathrm{HbA}$ in those who have inherited a $\beta^{+}$-thalassemia mutation. The mean level of $\mathrm{HbF}$ in 200 patients from Sri Lanka was approximately $28 \%$, ranging from less than $10 \%$ to $50 \%$; even higher levels of $\mathrm{HbF}$ have been reported from Thailand. Family studies reveal the carrier state for $\mathrm{HbE}$ in one parent and for $\beta$-thalassemia trait in the other. The laboratory findings associated with different complications are discussed in the following sections.

\section{Complications}

\section{Hypersplenism}

Splenomegaly, together with pooling of red cells and their increased rate of destruction, is extremely common. In the more severe phenotypes, it often progresses rapidly from the first few years

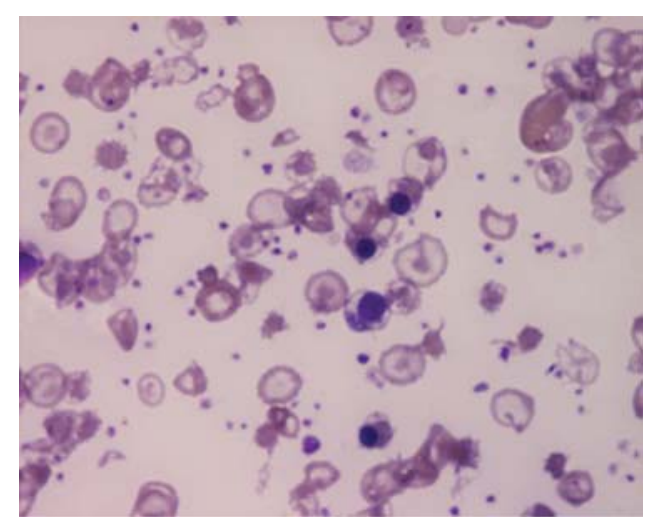

Figure 3. The peripheral blood film in hemoglobin E $\beta$ thalassemia after splenectomy showing numerous nucleated red cells and a high platelet count. 
of life, whereas in the milder phenotypes, although the spleen is palpable, it usually does not attain a size greater than $5-6 \mathrm{~cm}$ below the costal margin. Much less common, and usually in the milder phenotypes, splenomegaly may slowly increase over 10-20 years and only become a problem later in life. As well as resulting in increasing anemia, progressive enlargement of the spleen is quite often associated with pain and discomfort in the left upper quadrant.

\section{Infection}

Patients with $\mathrm{HbE} \beta$ thalassemia are susceptible to viral, bacterial, and fungal infection, which are common causes of mortality (Aswapokee et al. 1988a,b). In splenectomized patients, septicemia can be very acute and overwhelming, leading to death in a short period. Gram-negative and gram-positive bacteria are frequent causes of septicemia. Fungal infection with Pythium can lead to arterial occlusion and gangrene of the legs (Sathapatayavongs et al. 1989; Wanachiwanawin et al. 1993). The mechanism that causes increased susceptibility to infections is not known. Recent studies have suggested that patients with $\mathrm{HbE} \beta$ thalassemia may be more prone to infection by both $P$. falciparum and $P$. vivax malaria, particularly the latter, and that those who have undergone splenectomy may be even more susceptible (O’Donnell et al. 2009).

\section{Cardiac Disease}

Approximately half of the patients with $\mathrm{HbE} \beta$ thalassemia in Thailand die of heart failure. This is associated with failure of other organs, delayed growth and sexual maturation, hepatomegaly, and endocrinopathies. Organ failure results from iron deposition in the heart and other tissues (Vannasaeng et al. 1981; Sonakul et al. 1988; Thakerngpol et al. 1988) resulting from increased absorption and blood transfusion. Myocardial iron deposition is usually limited, occurring primarily as small granules in perinuclear areas, with later accumulation throughout the muscle fibers, predominantly subepicardial and occasionally subendocardial (Sonakul et al. 1984). The small amount of iron deposited in the heart is in marked contrast to enormous iron deposition in the liver and pancreas. Cardiomegaly is proportional to the severity of anemia and systolic murmurs are frequently present (Jootar and Fucharoen 1990). Chronic pericarditis following upper respiratory tract infection is frequently encountered, more commonly in splenectomized patients. A pericardial rub may be detected, often transiently. Intractable pericardial effusion may follow, causing cardiac tamponade and failure, and requires aspiration. In a very few cases, chronic constrictive pericarditis develops, requiring surgical intervention.

Heart rate variability (HRV) has been developed to determine cardiac autonomic function and is applied to investigate patients with thalassemia major (De Chiara et al. 2005). Studies of the HRV in HbE $\beta$ thalassemia have obtained similar results to those in thalassemia major (Rutjanaprom et al. 2009). The depressed HRV compared to normal suggests that HRV may be a marker of cardiac sympatho-vagal imbalance as well as an early indicator of cardiac involvement in both thalassemia major and $\mathrm{HbE} \beta$ thalassemia.

Pulmonary hypertension and right heart failure are discussed in the following sections.

\section{Hypoxemia}

The majority of splenectomized HbE $\beta$-thalassemia patients in Thailand develop hypoxemia with low arterial $\mathrm{pO}_{2}$ (Wasi et al. 1982). Platelet counts in these patients are double those of nonsplenectomized patients; young and larger platelets are also observed in the absence of the spleen. Platelet microaggregates have been detected in the circulation of these splenectomized patients. One hypothesis for the pathogenesis of hypoxemia in $\mathrm{HbE} \beta$ thalassemia is that platelets increase in number, are younger and more active after splenectomy, and aggregate in the circulation and in the pulmonary vasculature. Substances released during platelet aggregation may cause constriction of the terminal bronchioles leading to decreased oxygenation and hypoxemia. Administration of aspirin to inhibit platelet aggregation reduces the degree of hypoxemia in the majority of cases 
(Fucharoen et al. 1981), suggesting that aspirin should be routinely given to splenectomized patients with $\mathrm{HbE} \beta$ thalassemia. Interestingly, this combination of pulmonary hypertension and hypoxemia, together with right ventricular failure, has not been observed so frequently in other populations, suggesting that other factors may be involved in the Thai population.

\section{Thromboembolism}

Autopsy findings in a large number of Thai patients with $\mathrm{HbE} \beta$ thalassemia revealed striking pulmonary artery occlusion (Fig. 4) (Sonakul et al. 1980). Thromboembolism in $\mathrm{HbE} \beta$ thalassemia seems to involve platelets, a reactive thalassemic red cell surface, coagulation factors, and abnormal endothelium (Butthep et al. 2002; Pattanapanyasat et al. 2004).

\section{Hypertension, Convulsions, and Cerebral Hemorrhage}

Some patients in Thailand develop hypertension, convulsions, and cerebral hemorrhage after transfusion of 2 units or more of blood (Wasi et al. 1978). This complication may develop as late as 2 weeks after multiple transfusions, suggesting that blood volume overload is not the cause of hypertension. Monitoring blood pressure during and after blood transfusions with prompt antihypertensive intervention has reduced deaths from this complication. This syndrome has not been reported in other populations.

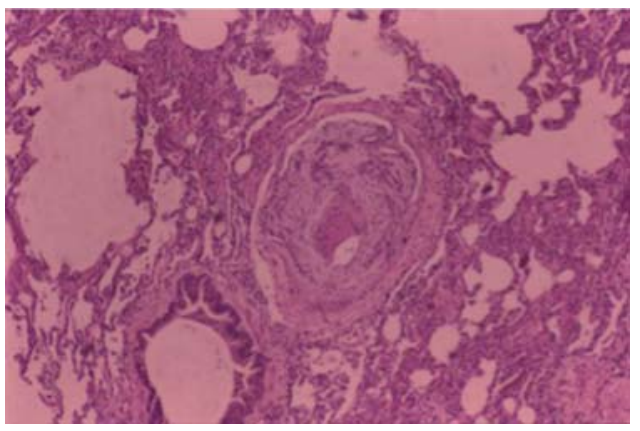

Figure 4. Pulmonary vascular occlusion in hemoglobin $\mathrm{E} \beta$ thalassemia after splenectomy.

\section{Extramedullary Hemopoiesis}

Erythropoiesis is massively increased to $10-15$ times normal because anemia stimulates erythropoietin production. Extensive erythropoiesis can be found in the liver, spleen, bone marrow, and in extramedullary sites. Erythropoietic masses in the spinal canal can cause spinal cord compression and paraplegia, and when they occur intracranially, convulsions may result (Issaragrisil et al. 1981). Massive erythropoiesis leads to fragility and distortion of the bones and decreases bone density because of osteoporosis and osteomalacia, as observed in irregularly transfused patients (Pootrakul et al. 1980).

\section{Jaundice, Gallstones, and Cholecystitis}

Some $\mathrm{HbE} \beta$-thalassemia patients have severe and persistent jaundice in the absence of definable liver disease. It turns out that this is a result of the homozygous inheritance of the TA(7) allele of the promoter of the glucuronyltransferase 1 gene, a polymorphism that is particularly common in Sri Lanka (Premawardhena et al. 2001). These patients have a highly significant increase in the incidence of gallstones. Homozygosity for the $\mathrm{TA}(7)$ allele occurs in $10 \%-25 \%$ of some populations of Africa and the Indian subcontinent but at a much lower frequency in Southeast Asia (Premawardhena et al. 2003). Stones are found in approximately $50 \%$ of $\mathrm{HbE} \beta$-thalassemia patients in Thailand (ChandcharoensinWilde et al. 1988). For the detection of biliary calculi, ultrasonography is more sensitive than oral cholecystography and plain abdominal films. Cholecystitis and ascending cholangitis may occur with abdominal pain, fever, and increasing jaundice (Vathanopas et al. 1988).

\section{Iron Overload}

Iron overload occurs commonly (Pootrakul et al. 1981). Excessive iron accumulates because of blood transfusions and enhanced gastrointestinal absorption. The skin is darkened and iron deposition occurs in the bone marrow, liver, spleen, heart, pancreas, and elsewhere (Sonakul et al. 1988; Thakerngpol et al. 1988). The related cardiac complications were discussed earlier. 
Although liver fibrosis from iron overload is common, ascites and other signs of cirrhosis are very rare. Diabetes mellitus, secondary to iron deposition in the pancreas, frequently develops in untreated adult patients (Vannasaeng et al. 1981). A terminal wasting stage occurs in some patients who survive to their fourth and fifth decades. They develop severe skin pigmentation, poor appetite, weight loss, and increasing anemia, and eventually die. This is believed to result from organ failure caused by uncontrolled tissue oxidation from chronic, severe iron overload.

Recently, it has been possible to obtain more direct data about the liver iron concentration in $\mathrm{HbE} \beta$ thalassemia using spin density projection assisted R2-MRI technology (Olivieri et al. 2011). These studies showed a marked variation in hepatic iron levels even in patients who had received only minimal transfusion. They also underlined the rather poor agreement between hepatic iron levels as measured in this way and serum ferritin values. Clearly, a great deal more work is required to try to determine the reasons for the variable rate of iron accumulation by increased intestinal absorption and, in particular, whether this reflects polymorphisms in one or more of the genes that are involved in the regulation of iron absorption.

\section{Other Endocrine Disorders}

As well as diabetes there are other important endocrine disorders that occur as a result of iron loading. In particular hypothyroidism and hypoparathyroidism are quite common and the former is frequently associated with growth retardation. It is vital, therefore, to carry out regular assessments of thyroid and parathyroid function in patients with $\mathrm{HbE} \beta$ thalassemia, regardless of the severity of their phenotype.

\section{Genotype-Phenotype Interaction \\ Definition of Severity}

Despite seemingly identical genotypes, compound heterozygotes for $\beta$ thalassemia and $\mathrm{HbE}$ have remarkably variable phenotypes. Notable are variations in the degree of anemia, growth, development, hepatosplenomegaly, and transfusion requirements. A novel scoring system based on six independent parameters-hemoglobin level, age at disease presentation, age at receiving first blood transfusion, requirement for transfusion, spleen size, growth and development-was able to separate patients into three distinctive severity categories: mild, moderate, and severe. The scoring system consisting of six clinical criteria scored as $0,0.5,1$, or 2 , according to clinical presentation. HbE $\beta$-thalassemia patients with total scores ranging from 0 to $3.5,4$ to 7 , and 7.5 to 10 are grouped as mild, moderate, and severe cases, respectively. The severe patients are very anemic and are usually transfusion dependent; some may have marked growth retardation, whereas the mild cases have mild anemia and usually have normal growth and development (Sripichai et al. 2008).

As indicated by recent studies in Sri Lanka, the application of a clearly defined scoring system for severity combined with a long period of observation and genetic and environmental analysis (Premawardhena et al. 2005; Olivieri et al. 2010) should help us to understand the factors that determine the broad range of severity of $\mathrm{HbE} \beta$ thalassemia.

\section{$\beta$-Thalassemia Mutations}

Although $\beta^{0}$ thalassemia is caused by many mutations, all result in absence of $\beta$-globin chain production by the abnormal gene. $\beta^{0}$ thalassemia is more severe than $\beta^{+}$thalassemia, in which a wide range of $\beta$-globin chain production is observed. In most countries with a high frequency of $\mathrm{HbE} \beta$ thalassemia, the common $\beta$-thalassemia mutations are either $\beta^{0}$ thalassemia or $\beta^{+}$thalassemia associated with very small amounts of $\beta$-globin chain synthesis. The fact that there is still considerable clinical heterogeneity in these patients is clearly not a result of variation in $\beta$-globin chain synthesis directed by the chromosome containing the $\beta$ thalassemia mutation. There are, however, certain milder forms of $\beta^{+}$thalassemia associated with much higher levels of $\beta$-chain production and, when inherited together with $\mathrm{HbE}$, produce a much milder form of $\mathrm{HbE} \beta$ thalassemia. The phenotypes and hemoglobin findings in 
patients of this type are summarized by Weatherall and Clegg (2001).

\section{Coinheritance of $\alpha$ Thalassemia}

The concomitant inheritance of $\alpha$ thalassemia or $\mathrm{Hb}$ Constant Spring may be responsible for less severe anemia and a milder phenotype in HbE $\beta^{0}$ thalassemia (Winichagoon et al. 1985, 1993). Coinheritance of $\alpha^{0}$ thalassemia with $\mathrm{HbE} \beta^{0}$ thalassemia may lead to so mild a condition that the individuals do not have a clinical abnormality that requires medical attention. Similar findings have been observed in Sri Lankan populations, in which the coinheritance of the heterozygous state for $\alpha^{+}$thalassemia has been found to result in a remarkable degree of amelioration of the clinical severity of $\mathrm{HbE} \beta$ thalassemia (Premawardhena et al. 2005).

\section{Association with Increased $\mathrm{HbF}$}

Coinheritance of determinants that increase $\mathrm{HbF}$ expression can ameliorate the severity of $\mathrm{HbE} \beta$ thalassemia. Inheritance of a chromosome with the $\mathrm{C} \rightarrow \mathrm{T}$ polymorphism that results in an Xmn-1 cleavage site at position -158 to the ${ }^{\mathrm{G}} \gamma$-globin gene is associated with increased $\mathrm{HbF}$ and milder anemia (Winichagoon et al. 1987). Two copies of this allele $(X m n-1+/+)$ are necessary to produce a significant clinical effect. Increased expression of the ${ }^{\mathrm{G}} \gamma$-globin gene was also detected in the Xmn-1 $+/+$ patients. This increase of $\gamma$-globin gene activity reduces the overall globin chain imbalance and thus ameliorates the anemia. The association between the $X m n-1+/+$ genotype and a highly significant increase in the absolute level of $\mathrm{HbF}$ and a milder phenotype has also been observed in patients with $\mathrm{HbE} \beta$ thalassemia in Sri Lanka (Premawardhena et al. 2005). It is likely that several other polymorphisms will have this effect (see later section and Sankaran and Orkin 2012).

\section{Amount of Alternatively Spliced $\beta^{\mathrm{E}}$-Globin mRNA}

An underproduction of $\beta$-globin chains from the $\beta^{\mathrm{E}}$-globin gene strongly suggests that alternative RNA splicing is of functional signifi- cance. The percentage of alternative spliced $\beta^{\mathrm{E}}$ globin mRNA was determined by the reverse transcriptase polymerase chain reaction technique in 14 patients with the same thalassemia mutation (Winichagoon et al. 1995). Preliminary results showed abnormally spliced $\beta^{\mathrm{E}}$-globin mRNA in patients with severe symptoms and low hemoglobin levels between $2.9 \%$ and $6.1 \%$, whereas those with higher hemoglobin levels had values from $1.6 \%$ to $2.6 \%$. The majority of patients with the Xmnl-negative genotype had more severe anemia and a higher percentage of abnormally spliced $\beta^{\mathrm{E}}$-globin mRNA. This indicated that the amount of alternatively spliced E-globin mRNA was a more important factor in determining severity of anemia than the pattern of Xmnl polymorphism or the level of HbF. Recently, Tubsuwan et al. used the allele-specific RT-qPCR to study $\beta^{\mathrm{E}}$-globin gene expression and found that the correctly to aberrantly spliced $\beta^{\mathrm{E}}$-globin mRNA ratio in $30 \%$ of mild $\mathrm{HbE} \beta$-thalassemia patients was higher than that of the severe patients. It appears therefore that the splicing process of $\beta^{\mathrm{E}}$-globin premRNA differs among $\mathrm{HbE} \beta$-thalassemia patients and serves as one of the modifying factors for disease severity (Tubsuwan et al. 2011). It will be important to determine whether this phenomenon occurs in other ethnic groups.

\section{Pyrimidine 5' Nucleotidase Deficiency}

In a Bangladeshi family, an individual homozygous for both $\mathrm{HbE}$ and pyrimidine $5^{\prime}$ nucleotidase deficiency was found. The patient had a severe hemolytic anemia in contrast to $\mathrm{HbE}$ homozygotes. Globin chain synthesis experiments showed that the mechanism underlying the interaction between these two genotypes was a marked decrease in the stability of $\mathrm{HbE}$ in pyrimidine $5^{\prime}$ nucleotidase-deficient red blood cells. In these cells, free $\alpha$-globin chains but $\operatorname{not} \beta^{\mathrm{E}}$-globin chains accumulated on the membrane. It was hypothesized that the marked instability of $\mathrm{HbE}$ in the enzyme-deficient cells resulted from oxidant damage to mildly unstable HbE (Rees et al. 1996). Clearly this interaction also has the potential to modify the phenotype of $\mathrm{HbE} \beta$ thalassemia. 


\section{Genome-Wide Association Study}

Recently, a genome-wide association study (GWAS) was performed in 618 Thai $\mathrm{HbE} \beta^{0}-$ thalassemia patients using the Illumina Human 610-Quad BeadChips array (Nuinoon et al. 2010). DNAs were extracted from 383 severe and 235 mild phenotypes, by a validated scoring system, after the exclusion of $\alpha$ thalassemia. Twenty-three single nucleotide polymorphisms (SNPs) in three independent genes/regions were identified as being significantly associated with the disease severity. The highest association was observed with SNPs in the $\beta$-globin gene cluster (chr.11p15). The second was identified in the intergenic region between the HBS1L and $M Y B$ genes (chr.6q23), and the third region was located in the BCL11A gene (chr.2p16.1). An association to HbF levels with SNPs in these three regions was observed. This result suggests that several genetic loci act in concert to influence $\mathrm{HbF}$ levels of $\mathrm{HbE} \beta^{0}$-thalassemia patients (see Sankaran and Orkin 2012).

\section{Variation in Adaptation to Anemia and Environmental Factors}

As already mentioned, there appears to be a reduction in erythropoietin production in relationship to a similar hemoglobin level with aging, a finding which may explain some of the phenotypic instability during the early years of life. Whether there is a genetic component to the magnitude of erythropoietin response remains to be determined. Undoubtedly, patients with $\mathrm{HbE} \beta$ thalassemia adapt more readily to low hemoglobin levels than those with other forms of $\beta$-thalassemia intermedia (Allen et al. 2010). Although as is the case for most inherited hemoglobin disorders, the role of the environment in modifying the phenotype has been neglected; recent studies suggest that patients with $\mathrm{HbE} \beta$ thalassemia are more susceptible to malaria infection, particularly that caused by $P$. vivax, than age-matched controls in the population (O'Donnell et al. 2009). There is also reasonable evidence that those who have been exposed to malaria tend to have larger spleens and fall into the more severe phenotypic categories. Much more work is required to fur- ther elucidate environmental factors that may modify the phenotype.

\section{Conclusion}

The genotypic factors that can be used to predict a mild phenotype in $\mathrm{HbE} \beta$ thalassemia are mild $\beta^{+}$-thalassemia mutations, the coinheritance of $\alpha$ thalassemia, the polymorphisms associated with $\mathrm{HbF}$ production such as homozygosity for $X m n-l$ restriction site $5^{\prime}$ to the ${ }^{G} \gamma$-globin gene and the BCL11A gene. Some complications of the disease such as severe jaundice are also affected by genetic modifiers. And it is also clear that at least some factors that modify the response to anemia or the environment of patients with this disease are also responsible for phenotypic diversity. But although progress has been made, it is still only possible to explain part of its wide phenotypic diversity.

\section{Treatment}

Because $\mathrm{HbE} \beta$ thalassemia has such a variable phenotype and patients with this disorderprobably because they have relatively lower levels of $\mathrm{HbF}$ and reflecting the oxygen affinity of HbE - are able to adapt to anemia better than patients with other forms of thalassemia intermedia, it is vital to observe babies and young children with this condition after presentation for a reasonable period before deciding on the best approach to management. It is important to remember that they may present with a particularly low hemoglobin level consequent to a recent infection, and it is particularly important therefore not to establish them on a regular transfusion until their steady-state hemoglobin level and level of growth and degree of splenomegaly has been assessed. Particularly in areas where malaria is endemic it is also important to exclude chronic $P$. vivax infection as a possible cause of rapidly progressive splenomegaly.

The hemoglobin level alone should not be the major factor in initiating transfusion. Rather, the broader picture should be considered with particular attention to growth failure, lack of activity, and the earlier appearance of skeletal change. If it is clear that the patient 
requires regular transfusion the regimen to be followed, including chelation, is similar to that for the management of thalassemia major (see Brittenham and Olivieri 2012). Those who do not require transfusion should be maintained on folic acid supplements and advised about the early treatment of infective episodes. Although some patients with increasing splenomegaly and evidence of hypersplenism may benefit from splenectomy, this should be avoided where possible because of the particularly high risk of infection.

Patients who do not require regular transfusion should have serum ferritin or hepatic MRI estimations at least twice per year. Increased iron levels should be controlled by intermittent courses of chelating agents.

Hydroxyurea therapy may increase HbF levels (Fucharoen et al. 1996), although recent studies in other populations have shown that this effect is not great, even when combined with erythropoietin. For those who present early with severe disease, bone marrow transplantation remains an important option (Issaragrisil 1994; Leelahavarong et al. 2010).

Rapidly expanding extramedullary hemopoietic masses, particularly involving the brain or spinal cord, require urgent treatment by blood transfusion, hydroxyurea, or possibly, radiotherapy. Limited experience in those with profound jaundice as a result of genetic inability to conjugate bilirubin suggest that, at least in some cases, very low doses of phenobarbitone may be helpful.

The first successful report of gene therapy in thalassemia involved a patient with $\mathrm{HbE}$ $\beta$ thalassemia (Cavazzana-Calvo et al. 2010). Although the patient showed clinical improvement and did not need further blood transfusion, it is not yet clear whether this is mainly because of the action of the inserted "normal" $\beta$-globin gene. The improvement also seems to be at least partly a result of an increase in $\mathrm{HbF}$ levels by an unknown mechanism.

\section{Prevention of $\mathrm{HbE} \beta$ Thalassemia}

Effective prevention programs for thalassemia have been demonstrated in many countries in which carrier rates for different types of thalassemia are very high (see Brittenham and Olivieri 2012). In Thailand, screening has improved by using an automatic high-performance liquid chromatography (HPLC) system (Fucharoen et al. 1998). In recent years, a nationwide program in Thailand has been developed to prevent homozygous $\beta$ thalassemia, $\mathrm{HbE} \beta$ thalassemia, and $\mathrm{Hb}$ Bart's hydrops fetalis, with encouraging results (Tongsong et al. 2000). The prospective screening consisted of osmotic fragility (OF) and $\mathrm{HbE}$ screening tests in pregnant women, followed by testing the husbands of the women with a positive result. Subsequently, the OF test was replaced by mean corpuscular volume (MCV) when automated cell counters became available nationwide. If both partners of the couple have a positive result, further diagnostic tests by HPLC and genotyping of the carrier are carried out. A pregnancy in which both partners of the couple are carriers is considered as a couple at risk, and further detailed counseling and prenatal diagnosis is offered for the severe thalassemia syndromes (Fucharoen and Winichagoon 2007).

Since the program began, the number of new cases of thalassemia in Thailand has gradually decreased. In the first few years of the program, its cost-effectiveness was evaluated and it was found that among a total pregnant population of 21,000 individuals that were screened, 80 affected fetuses had been identified and the pregnancy terminated. The total cost of the prevention program was about U.S. $\$ 257,140$, and the cost of management of these affected cases, if they had been born, would have been U.S. $\$ 7,200,000$. The cost-benefit ratio was $1: 28$, which indicates a highly cost-effective project.

\section{CONCLUSIONS}

$\mathrm{HbE} \beta$ thalassemia is a major public health problem in Southeast Asia and in other Asian countries. Although some progress has been made toward a better understanding of its pathophysiology and clinical management a great deal remains to be learned. Recent work has 
Hemoglobin E Thalassemias

made it absolutely clear that there must be other genetic modifiers to be discovered that are responsible for the variable phenotype. A better approach to predicting the phenotype is urgently required, particularly if prenatal diagnosis is to be widely used for the control of this condition and, even more so, if experimental forms of gene therapy become available in the future. Because it may be some time before there are more definitive forms of treatment, it is important to utilize the information that we already have more effectively. For example, in malarious areas it will be very important to conduct trials of malaria prophylaxis. With particular respect to the phenotype of patients with this condition early in life, and because recent evidence suggests that the erythropoietin response to anemia tends to decline with age, the possibility of transient periods of transfusion during maximum erythroid expansion should be seriously considered. And because genetic evidence indicates that the phenotype in this condition may be improved quite dramatically with only a modest increase in steady-state hemoglobin level, more efforts should be directed at trying to raise the $\mathrm{HbF}$ level in these patients.

\section{Other Interactions of $\mathrm{HbE}$}

This article has considered the most common and important clinical interactions of $\mathrm{HbE}$. Because it is so common it is not surprising that many rare interactions between this variant and a wide variety of structural hemoglobin variants and related conditions have been reported. The resulting disorders are described briefly in a recent review (Fucharoen and Weatherall 2009).

\section{ACKNOWLEDGMENTS}

This work is supported by the Office of the Higher Education Commission and Mahidol University under the National Research University Initiative and the National Center for Genetic Engineering, Thailand and The Wellcome Trust, UK. We thank Liz Rose for her help in preparing this work.

\section{REFERENCES}

* Reference is also in this collection.

Allen A, Fisher C, Premawardena A, Peto T, Allen S, Arambepola $\mathrm{K}$, Thayalsuthan $\mathrm{V}$, Olivieri $\mathrm{N}$, Weatherall $\mathrm{D}$. 2010. Adaptation to anemia in hemoglobin E- $\beta$ thalassemia. Blood 116: 5368-5370.

Aswapokee N, Aswapokee P, Fucharoen S, Wasi P. 1988a. A study of infective episodes in patients with $\beta$-thalassemia/Hb E disease in Thailand. Birth Defects 23: 513-520.

Aswapokee P, Aswapokee N, Fucharoen S, Sukroongreung S, Wasi P. 1988b. Severe infection in thalassemia: A prospective study. Birth Defects 23: 521-526.

* Brittenham G, Olivieri N. 2012. Cold Spring Harb Perspect Med (to be published).

Butthep P, Rummavas S, Wisedpanichkij R, Jindadamrongwech S, Fucharoen S, Bunyaratvej A. 2002. Increased circulating activated endothelial cells, vascular endothelial growth factor, and tumor necrosis factor in thalassemia. Am J Hematol 70: 100-106.

Cavazzana-Calvo M, Payen E, Negre O, Wang G, Hehir K, Fusil F, Down J, Denaro M, Brady T, Westerman K, et al. 2010. Transfusion independence and HMGA2 activation after gene therapy of human $\beta$-thalassaemia. Nature 467: $318-322$.

Chandcharoensin-Wilde C, Chairoongruang S, Jitnuson P, Fucharoen S, Vathanopas V. 1988. Gallstones in thalassemia. Birth Defects 23: 263-267.

Chernoff AI, Minnich V, Na-Nakorn S, Tuchinda S, Kashamsant C, Chernoff RR. 1956. Studies on hemoglobin E: I. The clinical, hematologic, and genetic characteristics of the hemoglobin E syndromes. J Lab Clin Med 47: 490-498.

De Chiara B, Crivellaro W, Sara R, Ruffini L, Parolini M, Fesslova V, Carnelli V, Fiorentini C, Parodi O. 2005. Early detection of cardiac dysfunction in thalassemic patients by radionuclide angiography and heart rate variability analysis. Eur J Haematol 74: 517-522.

Frischer H, Bowman J. 1975. Hemoglobin E, an oxidatively unstable mutation. J Lab Clin Med 85: 531-539.

Fucharoen S, Weatherall DJ. 2009. Hemoglobin E disorders. In Disorders of hemoglobin (ed. Steinberg MH, Forget BG, Higgs DR, Weatherall DJ), pp. 417-433. Cambridge University Press, Cambridge.

Fucharoen S, Winichagoon P. 2007. Prevention and control of thalassemia in Asia. Asian Biomed 1: 1-6.

Fucharoen S, Youngchaiyud P, Wasi P. 1981. Hypoxaemia and the effect of aspirin in thalassaemia. Southeast Asian J Trop Med Public Health 12: 90-93.

Fucharoen S, Winichagoon P, Thonglairuam V. 1988a. Betathalassemia associated with $\alpha$-thalassemia in Thailand. Hemoglobin 12: 581-592.

Fucharoen S, Winichagoon P, Thonglairuam V, Wasi P. 1988b. EF Bart's disease: Interaction of the abnormal $\alpha$ and $\beta$-globin genes. Eur J Haematol 40: 75-78.

Fucharoen S, Siritanaratkul N, Winichagoon P, Chowthaworn J, Siriboon W, Muangsup W, Chaicharoen S, Poolsup N, Chindavijak B, Pootrakul P, et al. 1996. Hydroxyurea increases hemoglobin $\mathrm{F}$ levels and improves 
the effectiveness of erythropoiesis in $\beta$-thalassemia/hemoglobin E disease. Blood 87: 887-892.

Fucharoen S, Winichagoon P, Wisedpanichkij R, Sae-Ngow B, Sriphanich R, Oncoung W, Muangsapaya W, Chowthaworn J, Kanokpongsakdi S, Bunyaratvej A, et al. 1998. Prenatal and postnatal diagnoses of thalassemias and hemoglobinopathies by HPLC. Clin Chem 44: 740-748.

* Higgs DR. 2012. The molecular basis of $\alpha$ thalassemia. Cold Spring Harb Perspect Med doi: 10.1101/cshperspect. a011718.

Issaragrisil S. 1994. Bone marrow transplantation in Thailand. Bone Marrow Transplant 13: 721-723.

Issaragrisil S, Piankigagum A, Wasi P. 1981. Spinal cord compression in thalassemia. Report of 12 cases and recommendations for treatment. Arch Intern Med 141: $1033-1036$.

Itano HA, Bergren WR, Sturgeon P. 1954. Identification of a fourth abnormal human hemoglobin. J Am Chem Soc 76: 2278.

Jootar P, Fucharoen S. 1990. Cardiac involvement in $\beta$-thalassemia/hemoglobin E disease: Clinical and hemodynamic findings. Southeast Asian J Trop Med Public Health 21: 269-273.

Leelahavarong P, Chaikledkaew U, Hongeng S, Kasemsup V, Lubell Y, Teerawattananon Y. 2010. A cost-utility and budget impact analysis of allogeneic hematopoietic stem cell transplantation for severe thalassemic patients in Thailand. BMC Health Serv Res 10: 209.

Minnich V, Na-Nakorn S, Chongchareonsuk S, Kochaseni S. 1954. Mediterranean anemia: A study of 32 cases in Thailand. Blood 9: 1-23.

* Musallam KM, Taher AT, Rachmilewitz EA. 2012. $\beta$-Thalassemia intermedia: A clinical perspective. Cold Spring Harb Perspect Med doi: 10.1101/cshperspect.a013482.

* Nienhuis AW, Nathan DG. 2012. Pathophysiology and clinical manifestations of the $\beta$ thalassemias. Cold Spring Harb Perspect Med doi: 10.1101/cshperspect.a011726.

Nuinoon M, Makarasara W, Mushiroda T, Setianingsih I, Wahidiyat PA, Sripichai O, Kumasaka N, Takahashi A, Svasti S, Munkongdee T, et al. 2010. A genome-wide association identified the common genetic variants influence disease severity in $\beta 0$-thalassemia/hemoglobin $\mathrm{E}$. Hum Genet 127: 303-314.

O'Donnell A, Premawardhena A, Arambepola M, Allen SJ, Peto TE, Fisher CA, Rees DC, Olivieri NF, Weatherall DJ. 2007. Age-related changes in adaptation to severe anemia in childhood in developing countries. Proc Natl Acad Sci 104: $9440-9444$.

O'Donnell A, Premawardhena A, Arambepola M, Samaranayake R, Allen SJ, Peto TE, Fisher CA, Cook J, Corran $\mathrm{PH}$, Olivieri NF, et al. 2009. Interaction of malaria with a common form of severe thalassemia in an Asian population. Proc Natl Acad Sci 106: 18716-18721.

Olivieri NF, Thayalsuthan V, O’Donnell A, Premawardena A, Rigobon C, Muraca G, Fisher C, Weatherall DJ. 2010. Emerging insights in the management of hemoglobin E $\beta$ thalassemia. Ann NY Acad Sci 1202: 155-157.

Olivieri NF, Thayalasuthan V, Muraca G, Weatherall D, Kim C, Premawardhena A, Perera A, O'Donnell A, St Pierre T. 2011. Relationship between serum ferritin and liver iron concentration in hemoglobin $\mathrm{E}$ thalassemia. 16th
Congress of European Hematology Association, London, June 9-12.

Orkin SH, Kazazian HH, Antonarakis SE, Ostrer H, Goff SC, Sexton JP. 1982. Abnormal RNA processing due to the exon mutation of $\beta^{\mathrm{E}}$-globin gene. Nature 300: 768769.

Pattanapanyasat K, Noulsri E, Fucharoen S, Lerdwana S, Lamchiagdhase P, Siritanaratkul N, Webster HK. 2004. Flow cytometric quantitation of red blood cell vesicles in thalassemia. Cytometry B Clin Cytom 57: 23-31.

Pootrakul P, Rugkiatsakul R, Wasi P. 1980. Increased transferrin iron saturation in splenectomized thalassaemia patients. Brit J Haematol 46: 143-145.

Pootrakul P, Vougsmasa V, Laongpanich P, Wasi P. 1981. Serum ferritin levels in thalassemias and the effect of splenectomy. Acta Haematol 66: 244-250.

Premawardhena A, Fisher CA, Fathiu F, de Silva S, Perera W, Peto TE, Olivieri NF, Weatherall DJ. 2001. Genetic determinants of jaundice and gallstones in haemoglobin E $\beta$ thalassaemia. Lancet 357: 1945-1946.

Premawardhena A, Fisher CA, Liu YT, Verma IC, de Silva S, Arambepola M, Clegg JB, Weatherall DJ. 2003. The global distribution of length polymorphisms of the promoters of the glucuronosyltransferase 1 gene (UGT1A1): Hematologic and evolutionary implications. Blood Cells $\mathrm{Mol}$ Dis 31: 98-101.

Premawardhena A, Fisher CA, Olivieri NF, de Silva S, Arambepola M, Perera W, O'Donnell A, Peto TEA, Viprakasit V, Merson L, et al. 2005. Haemoglobin E $\beta$ thalassaemia in Sri Lanka. Lancet 366: 1467-1470.

Rees DC, Duley J, Simmonds HA, Wonke B, Thein SL, Clegg JB, Weatherall DJ. 1996. Interaction of hemoglobin E and pyrimidine $5^{\prime}$ nucleotidase deficiency. Blood 88: 2761-2767.

Rees DC, Clegg JB, Weatherall DJ. 1998. Is hemoglobin instability important in the interaction between hemoglobin $\mathrm{E}$ and $\beta$ thalassemia? Blood 92: 2141-2146.

Rutjanaprom W, Kanlop N, Charoenkwan P, Sittiwangkul R, Srichairatanakool S, Tantiworawit A, Phrommintikul A, Chattipakorn S, Fucharoen S, Chattipakorn N. 2009. Heart rate variability in $\beta$-thalassemia patients. Eur $J$ Haematol 83: 483-489.

* Sankaran VG, Orkin SH. 2012. The switch from fetal to adult hemoglobin. Cold Spring Harb Perspect Med doi: 10.1101/cshperspect.a011643.

Sathapatayavongs B, Leelachaikul P, Prachaktam R, Atichartakarn V, Sriphojanart S, Trairatvorakul P, Jirasiritham S, Nontasut S, Eurvilaichit C, Flegel T. 1989. Human pythiosis associated with thalassemia hemoglobinopathy syndrome. J Infect Dis 159: 274-280.

Sonakul D, Pacharee P, Laohapand T, Fucharoen S, Wasi P. 1980. Pulmonary artery obstruction in thalassaemia. Southeast Asian J Trop Med Public Health 11: 516-523.

Sonakul D, Pacharee P, Wasi P, Fucharoen S. 1984. Cardiac pathology in 47 patients with $\beta$ thalassaemia/haemoglobin E. Southeast Asian J Trop Med Public Health 15: 554-563.

Sonakul D, Pacharee P, Thakerngpol K. 1988. Pathologic findings in 76 autopsy cases of thalassemia. Birth Defects 23: $157-176$. 
Hemoglobin E Thalassemias

Sripichai O, Makarasara W, Munkongdee T, Kumkhaek C, Nuchprayoon I, Chuansumrit A, Chuncharunee S, Chantrakoon N, Boonmongkol P, Winichagoon P, et al. 2008. A scoring system for the classification of $\beta$ thalassemia/Hb E disease severity. Am J Hematol 83: $482-484$.

Thakerngpol K, Sonakul D, Fucharoen S, Vathanopas V, Stitnimankarn T. 1988. Histochemical study of liver tissue from thalassemic patients. Birth Defects 23: 193-198.

* Thein SL. 2012. Molecular basis of $\beta$ thalassemia. Cold Spring Harb Perspect Med doi: 10.1101/cshperspect. a011700.

Thonglairuam V, Winichagoon P, Fucharoen S, Wasi P. 1989. The molecular basis of AE-Bart's disease. Hemoglobin 13: $117-124$.

Tongsong T, Wanapirak C, Sirivatanapa P, Sanguansermsri T, Sirichotiyakul S, Piyamongkol W, Chanprapaph P. 2000. Prenatal control of severe thalassaemia: Chiang Mai strategy. Prenat Diag 20: 229-234.

Traeger J, Wood WG, Clegg JB, Weatherall DJ, Wasi P. 1980. Defective synthesis of $\mathrm{Hb} \mathrm{E}$ is due to reduced levels of $\beta \mathrm{E}$ mRNA. Nature 288: 497-499.

Tubsuwan A, Munkongdee T, Jearawiriyapaisarn N, Boonchoy C, Winichagoon P, Fucharoen S, Svasti S. 2011 Molecular analysis of globin gene expression in different thalassaemia disorders: Individual variation of $\beta(E)$ premRNA splicing determine disease severity. Brit J Haematol 154: 635-643.

Vannasaeng S, Ploybutr S, Visutkul P, Tandhanand S, Suwanik R, Wasi P. 1981. Endocrine function in thalassaemia. Clin Endocrinol (Oxf) 14: 165-173.

Vathanopas V, Fucharoen S, Chandrcharoensin-Wilde C, Sukroongreung S, Nilakul C. 1988. Cholecystectomy in thalassemia. Birth Defects 23: 269-273.

* Vichinsky E. 2012. Natural history and clinical manifestations of the $\alpha$ thalassemias. Cold Spring Harb Perspect Med doi: 10.1101/cshperspect.a011742.

Wanachiwanawin W, Thianprasit M, Fucharoen S, Chaiprasert A, Sudasna N, Ayudhya N, Sirithanaratkul N, Piankijagum A. 1993. Fatal arteritis due to Pythium insidiosum infection in patients with thalassaemia. Trans $R$ Soc Trop Med Hyg 87: 296-298.
Wasi P, Sookanek M, Pootrakul S, Na-Nakorn S, Suingdumrong A. 1967. Haemoglobin $\mathrm{E}$ and $\alpha$-thalassaemia. $\mathrm{Br}$ Med J 4: 29-32.

Wasi P, Na-Nakorn S, Pootrakul S, Sookanek M, Disthasongcham P, Pornpatkul M, Manich V. 1969. Alphaand $\beta$-thalassemia in Thailand. Ann NY Acad Sci 165: 60-82.

Wasi P, Na-Nakorn S, Pootrakul P, Sonakul D, Piankijagum A, Pacharee P. 1978. A syndrome of hypertension, convulsions, and cerebral haemorrhage in thalassaemic patients after multiple blood transfusions. Lancet ii: 602-604.

Wasi P, Fucharoen S, Younghchaiyud P, Sonakul D. 1982. Hypoxemia in thalassemia. Birth Defects 18: 213-217.

Weatherall DJ, Clegg JB. 2001. The thalassaemia syndromes. Blackwell Science, Oxford.

Wickramasinghe SN, Lee MJ. 1997. Observations on the relationship between g-globin chain content and globin chain precipitation in thalassaemic erythroblasts and on the composition of erythroblastic inclusions in $\mathrm{Hb} \mathrm{E} / \beta$-thalassaemia. Eur J Haematol 59: 305-309.

* Williams TN, Weatherall DJ. 2012. World distribution, population genetics, and health burden of the hemoglobinopathies. Cold Spring Harb Perspect Med doi: 10.1101/ cshperspect.a011692.

Winichagoon P, Fucharoen S, Weatherall DJ, Wasi P. 1985. Concomitant inheritance of $\alpha$-thalassemia in $\beta^{0}$-thalassemia/Hb E disease. Am J Hematol 20: 217-222.

Winichagoon P, Fucharoen S, Thonglairoam V, Wasi P. 1987. Different severity of homozygous $\beta$-thalassemia among siblings. Hum Genet 76: 296-297.

Winichagoon P, Thonglairoam V, Fucharoen S, Wilairat P, Fukimaki Y, Wasi P. 1993. Severity differences in $\beta$-thalassaemia haemoglobin E syndromes: Implication of genetic factors. Brit J Haematol 83: 633-639.

Winichagoon P, Fucharown S, Wilairat P, Chihara K, Fukumaki Y. 1995. The role of alternatively spliced $\beta^{\mathrm{E}}$-globin mRNA on clinical severity of $\beta$-thalassemia/hemoglobin E disease. Southeast Asian J Trop Med Public Health 26: 241-245. 


\section{$\&_{\mathrm{CSH}}^{\infty} \&$ Cold Spring Harbor $\stackrel{\text { PERSPECTIVES }}{\longrightarrow \infty_{\infty}}$ Perspectives in Medicine}

\section{The Hemoglobin E Thalassemias}

Suthat Fucharoen and David J. Weatherall

Cold Spring Harb Perspect Med 2012; doi: 10.1101/cshperspect.a011734

Subject Collection

For additional articles in this collection, see http://perspectivesinmedicine.cshlp.org/cgi/collection/ 